\title{
Cannabis and Autoimmunity: Possible Mechanisms of Action
}

\author{
Valeria Giorgi (1D) \\ Daniela Marotto ${ }^{2}$ \\ Alberto Batticciotto ${ }^{3}$ \\ Fabiola Atzeni ${ }^{4}$ \\ Sara Bongiovanni ${ }^{1}$ \\ Piercarlo Sarzi-Puttini ${ }^{1}$ \\ 'Rheumatology Unit, Internal Medicine \\ Department, ASST Fatebenefratelli-Sacco, \\ Milan University School of Medicine, Milan, \\ Italy; ${ }^{2}$ Rheumatology Unit, ATS Sardegna, \\ P. Dettori Hospital, Tempio Pausania, Italy; \\ ${ }^{3}$ Rheumatology Unit, Internal Medicine \\ Department, ASST Settelaghi, Ospedale Di \\ Circolo - Fondazione Macchi, Varese, Italy; \\ ${ }^{4}$ Rheumatology Unit, Department of \\ Clinical and Experimental Medicine, \\ University of Messina, Messina, Italy
}

\begin{abstract}
Medical cannabis (MC) describes the usually inhaled or ingested use of a cannabis plant or cannabis extract for medicinal purposes. The action of whole cannabis plants is extremely complex because their large number of active compounds not only bind to a plethora of different receptors but also interact with each other both synergistically and otherwise. Renewed interest in the medicinal properties of cannabis has led to increasing research into the practical uses of cannabis derivatives, and it has been found that the endocannabinoid system (particularly CB2 receptor activation) is a possible target for the treatment of inflammatory and the autoimmune diseases related to immune cell activation. However, in vivo findings still lack, creating difficulties in applying translational cannabinoid research to human immune functions. In this review, we summarized the main mechanisms of action of medical cannabis plant especially regarding the immune system and the endocannabinoid system, looking at preliminary clinical data in three most important autoimmune diseases of three different specialities: rheumatoid arthritis, multiple sclerosis and inflammatory bowel disease.
\end{abstract}

Keywords: cannabis, cannabis derivatives, cannabidiol, tetrahydrocannabinol, terpenes, autoimmunity, auto-antibodies

\section{Introduction}

Cannabis is one of the oldest of cultivated plants, and has been used as a raw material, food and medicinal drug for thousands of years. ${ }^{1-4}$ It contains 538 chemical compounds, of which just 100 are natural phytocannabinoids (PCs) ${ }^{5}$ which are usually divided into the 10 subclasses of delta 9-tetrahydrocannabinol (THC), D8THC, cannabigerol (CBG), cannabichromene (CBC), cannabidiol (CBD), cannabinodiol, cannabielsoin, cannabicyclol, cannabinol (CBN), cannabitriol, and miscellaneous. The CBD and D9THC subclasses have so far received the most scientific attention: Gaoni and Mechoulam were the first to isolate THC and CBD in order to determine their structure and stereochemistry, and they subsequently synthesised them in the 1960s. ${ }^{6}$ PCs are mainly secreted by the trichomes of female plants (the glandular protuberances found on the leaves and stems) in the form of a resin whose wealth of PCs (mainly THC) and terpenoids (eg, pinene, limonene, caryophyllene) give the plants their characteristic smell.

In this paper, we provided a brief description of cannabis as a medicinal remedy, synthesized the main sites of action of the cannabis plant with a special regard to the immune system, and tried to explain whether medical cannabis action on the endocannabinoid system may be of help for patients with autoimmune diseases. In conclusion, we summarized preliminary clinical data about medical cannabis in the
Correspondence: Valeria Giorgi

Email vale.gio@fastwebnet.it 
three most important autoimmune diseases of three different specialities: rheumatoid arthritis, multiple sclerosis and inflammatory bowel disease.

\section{Medical Cannabis}

Medical cannabis (MC) refers to the plant or an extract (usually with a specific relative amount of THC and CBD) used for medical purposes. The preparations may be administered by means of vaporisation and inhalation, ingestion, or topical applications; the use of vaginal, rectal or sublingual administrations is less frequent. ${ }^{7}$ Oral cannabis formulations take effect 30-90 minutes after ingestion, and their effect peaks after 2-4 hours; and the approximate half-life of THC is eight days in fat, ${ }^{8,9}$ since PCs are highly lipophilic. ${ }^{10}$ Furthermore, it seems that the biodistribution of orally ingested CBD and THC is greater in the lymphoid tissues of the intestinal lymphatic system than in the larger lymphatic tissue of the central compartment, ${ }^{11}$ which may be particularly useful when treating chronic intestinal conditions. Conversely, its delivery to the lungs aids rapid absorption and leads to an early onset of action (after only one minute) that peaks after 30 minutes at most. This suggests that this route of administration is best in the case of more acute conditions, such as multiple sclerosis-associated spasticity. The drawback is that the faster THC reaches the brain, the more likely the occurrence of side effects. ${ }^{12}$ Mild, dose-dependent, acute adverse events are well documented: the most frequent are drowsiness, dry mouth, dizziness, vertigo, and nausea, but others include blurred vision, tachycardia, gastrointestinal disturbances (diarrhea/stipsis, lost/increased appetite, dyspepsia), and muscle spasms. ${ }^{13-16}$ THC-related side effects (fatigue, tachycardia and dizziness) can be avoided by very slow dose titration, which also promotes tolerance to its psychoactive side effects. ${ }^{16}$

\section{Pharmacodynamics and the Endocannabinoid System}

THC binds to PPAR $\gamma$ receptors, GPR55, GPR18, TRPA1 (or capsaicin receptors, which are predominantly expressed in the nociceptive neurons of the peripheral nervous system but are also found in the central nervous system), TRPV2, TRPV3, TRPV4, several glutamate receptors, glycine receptors, and adenosine receptors, and acts as an antagonist of 5-hydroxytryptamine (HT)3 receptors and TRPM8. It has recently been discovered that GPR55, which is coupled to a G-alpha protein and was once considered an orphan receptor, is activated not only by THC but also by CBD, certain synthetic cannabinoids, AEA and 2-AG, and its activation increases intracellular calcium levels. $^{17}$

CBD acts as an agonist of TRPA1, TRPV1, TRPV2, TRPV3, PPAR $\gamma$, 5-HT1A, A2 and A1 adenosine, an antagonist of GPR55, GPR18, and 5-HT3A, and an inverse agonist of GPR3, GPR6, and GPR $12,{ }^{18}$ and can also down-regulate the enzymes FAAH and 5-LOX. ${ }^{19-21}$

In the last decade, most of the attention has been drawn on the endocannabinoid system. The endocannabinoid system is a human biological system that consists of cannabinoid (CB) receptors and their endogenous ligands (endocannabinoids) and modulating enzymes. An increasing number of endocannabinoids have recently been discovered, including arachidonoyl ethanolamide, also called anandamide (AEA), 2-arachidonoyl glycerol (2-AG), ${ }^{22,23}$ 2-arachidonoyl glyceryl ether (noladin ether, 2-AGE), O-arachidonoylethanolamine (virodhamine), $\mathrm{N}$-arachidonoyldopamine (NADA), and oleic acid amide (oleamide, OA). ${ }^{24}$ Endocannabinoid-degrading enzymes include fatty acid amide hydrolases (FAAH) and monoacylglycerol lipase (MAGL). Anandamide is mainly degraded by FAAH, but also by cyclooxygenase- 2 (COX-2) and lipoxygenases (LOXs); $2-\mathrm{AG}$ is degraded by MAGL, and sometimes by COX-2, LOXs and minor enzymes such as $\alpha / \beta$ hydrolase- 6 and $\alpha / \beta$ hydrolase- $12^{25}$. Endocannabinoids are lipophilic and it is believed that, like eicosanoids, they are produced and released on demand. In addition to their interactions with CB receptors, their interactions with other molecular targets make them highly flexible, which accounts for the complexity of the system as a whole and the biological action of the individual cannabinoids. $^{26}$

CB1 receptors are mainly present in the central nervous system (CNS), but also found peripherally in hepatic, intestinal and adipose tissue, ${ }^{27}$ the eye, cardiovascular system, pancreas, immune system, bone, skin, and skeletal muscle, thus suggesting a potentially enormous periphery/ brain network of connections. ${ }^{28} \mathrm{CB} 2$ receptors are often called peripheral not only because they are mainly found in the immune system, ${ }^{29}$ but also because their activation is largely devoid of psychotropic effects. ${ }^{30}$ They are also present in microglial cells, ${ }^{31}$ and on chondrocytes, osteocytes, and fibroblasts - all cells that take part in the inflammation of the autoimmune diseases discussed in this article. Within the immune system, CB2 expression is higher in lymph nodes and spleen than in peripheral 
blood cells, and varies in different cell sub-populations (B cells $>$ NK cells $>$ monocytes $>$ neutrophils $>$ CD8+ T cells $>$ CD4+ T cells). ${ }^{32,33}$

Much of CBD biological activity is independent of $\mathrm{CB}$ receptors, as has been demonstrated by its suppression of cytokine production in $\mathrm{CB} 1$ and $\mathrm{CB} 2$ receptor knock-out mice. ${ }^{34}$ Some data suggest that $\mathrm{CBD}$ can indirectly activate CB1 and CB2 by increasing AEA and 2-AG levels. ${ }^{35}$ Indirect targeting of the CB system is actually a well-known pharmacological technique: the most widely used analgesic drug is the decades-old paracetamol, which acts by producing AM404 and thus interfering with the reuptake of anandamide. ${ }^{36}$

THC has quite a high affinity for both $\mathrm{CB}$ receptors, but its efficacy depends on receptor density and coupling efficiency: ${ }^{37}$ ie, it mainly acts as an antagonist of endocannabinoids in tissues characterised by lower $\mathrm{CB}$ receptor density. $\mathrm{CBD}$ has less affinity for $\mathrm{CB}$ receptors and, more particularly, is a negative allosteric modulator of $\mathrm{CB} 1$, thus probably making it an antagonist of some of the effects of THC when they are concomitantly administered. ${ }^{38-40}$ However, a recent in vivo study did not confirm this hypothesis. ${ }^{41}$

\section{Medical Cannabis and the Immune System}

The activities of the large number of compounds contained in whole cannabis plants is extremely complex because the compounds themselves not only bind to a plethora of different receptors but also interact with each other both synergistically and otherwise: ${ }^{42}$ for example, pinene is an acetylcholinesterase inhibitor that may decrease the shortterm memory impairment induced by THC. ${ }^{16}$ What follows is a brief summary of the activity of other PCs and terpenes (which have been more extensively reviewed elsewhere). ${ }^{43}$

$\mathrm{CBG}$ is an AEA reuptake inhibitor which, when combined with $\mathrm{CBD}$, has anti-inflammatory activity as it reduces the expression of tumour necrosis factor (TNF) and up-regulates interleukin (IL)-10 and IL-37 levels. ${ }^{44}$ $\mathrm{CBC}$ is also an agonist of $\mathrm{CB}$ receptor $2,{ }^{45}$ and $\mathrm{CBN}$ inhibits COX, LOX, and P450 cytochrome enzymes.

Terpenes are very promising compounds as they have a variety of positive (analgesic, anti-depressant, anti-oxidant, and anti-bacterial) functions, ${ }^{42}$ but the possible contribution of adding terpenoids to cannabinoids is uncertain. ${ }^{43}$ It has been reported that caryophyllenes are anti-microbial, antiproliferative, anti-fungal, anti-oxidant and anti-inflammatory acetylcholinesterase inhibitors; ${ }^{46}$ D-limonene may be antiinflammatory as it mediates the inhibition of pro- inflammatory mediators, leukocyte migration, and vascular permeability. ${ }^{47}$ Gamma-terpinene has an effect on the proand anti-inflammatory macrophage production of cytokines, particularly through the IL-10 axis. ${ }^{48}$

$\mathrm{CB}$ receptors are $\mathrm{G}$ protein-coupled receptors whose activation inhibits adenylate cyclase. By reducing cAMP levels, they decrease protein kinase $\mathrm{A}$ inhibition of $\mathrm{K}+$ channels, thus decreasing cell $\mathrm{K}+$ levels. Other signalling routes are the activation of mitogen-activated protein kinase and phosphoinositide-3-kinase. ${ }^{49} \mathrm{CB}$ receptor activation also activates $\mathrm{K}_{\mathrm{ir}}$ channels and inhibits $\mathrm{N}$ - or $\mathrm{P} / \mathrm{Q}$-type $\mathrm{Ca} 2+$ channels. A postsynaptic increase in neuronal calcium can trigger the biosynthesis and release of endocannabinoids, which then bind presynaptically to CB1 and inhibit neurotransmitter release in the synaptic cleft in a process known as retrograde signalling. ${ }^{50}$

The final effect clearly depends on the location of the $\mathrm{CB} 1$ receptors. It has been demonstrated that in vivo THC administration increases the release of acetylcholine, dopamine and glutamate in certain rat brain areas, probably as a result of a CB1-mediated decrease in inhibitory neurotransmitters ${ }^{51,52}$ It has also been demonstrated that $\mathrm{CB} 1$ receptor activation may play a neuroprotective role in some of the modulatory systems involved in neurodegeneration $^{53,54}$ and neuroinflammation. ${ }^{5,56}$ The mechanism of action of CB2 receptors is similar.

$\mathrm{CB}$ receptor binding has many effects on immune cells, but it mainly decreases immune system activation and immune cell migration by inhibiting immune cell mobilisation, inducing apoptosis, and suppressing transcription factors and cytokine release. Table 1 summarises these functions by type of immune cell.

$B$ cells are the immune cells with the highest levels of $\mathrm{CB} 1$ and $\mathrm{CB} 2$ receptors. Cannabinoids can decrease the production of antibodies in animals and humans, ${ }^{76-78}$ but their effect on B cell proliferation is still unclear. In T cells, cannabinoids clearly regulate $\mathrm{T}$ cell proliferation as $\mathrm{T}$ cell apoptosis is increased by AEA and CBD and decreased in CB2-deficient mice, and both AEA and THC decrease T cell proliferation $^{79-81}$ (although some studies suggest that CBD has a more potent anti-proliferative effect than THC). ${ }^{11}$

Macrophages also express CB receptors: $:^{82,83}$ the activation of $\mathrm{CB} 2$ receptors blocks monocyte migration, ${ }^{84,85}$ but induces phagocytosis and chemokine release. ${ }^{86}$ THC increases macrophage apoptosis and inhibits the differentiation of human monocytes into antigen-presenting dendritic cells. ${ }^{80,87}$

Immunomodulation is apparently mainly regulated by inhibiting immune cell mobilisation and increasing apoptosis: endocannabinoids decrease neutrophil and 
Table I Cannabinoid Mechanisms of Immune Suppression

\begin{tabular}{|c|c|c|c|c|}
\hline Targets & Mechanism of Action & In vivo & In vitro & References \\
\hline PBMCs & Decreasing levels of cytokines TNF-a, IFN-y, and IL-Ia. Increasing apoptosis & & $\sqrt{ }$ & $\begin{array}{l}\text { Watzl B et al }{ }^{57} \\
\text { Watzl B et al } \\
\text { Nichols JM et al } \\
\text { Wu HY et al. } \\
\text { Jenny } M \text { et al. }\end{array}$ \\
\hline T lymphocytes & $\begin{array}{l}\text { Influencing the balance of inflammatory ThI7 and regulatory T-cells by inducing a } \\
\text { regulatory phenotype. Decreasing T cell infiltration and proliferation by down- } \\
\text { regulating IL-2, IL-6, IL-8, TNF } \alpha \text {, IFN- } \gamma \text {, and IL- } 17 \text { production, and IL- I7A mRNA } \\
\text { transcripts }\end{array}$ & $\sqrt{ }$ & $\sqrt{ }$ & $\begin{array}{l}\text { Almogi-Hazan O et al. }{ }^{18} \\
\text { Kozela E et al. }{ }^{62} \\
\text { Jan TR et al. }{ }^{63} \\
\text { Chen } W \text { et al. } \\
\text { Devinsky O et al. } .^{65} \\
\text { Elliott DM et al. }{ }^{66} \\
\text { Selvi E et al }{ }^{67} \\
\text { Kinsey SG et al. }{ }^{68} \\
\text { Gentili M et al. } .^{69} \\
\text { Malfait AM et al. }{ }^{70}\end{array}$ \\
\hline B lymphocytes & Increasing antibody responses & $\sqrt{ }$ & & Shapiro CM et al. ${ }^{71}$ \\
\hline Neutrophils & $\begin{array}{l}\text { Reducing the stimulation of neutrophil degranulation, chemotaxis, and mast cell/ } \\
\text { basophil activation. }\end{array}$ & & $\sqrt{ }$ & $\begin{array}{l}\text { McHugh D et al. } \\
\text { Walter L et al. }{ }^{73} \\
\text { Giudice ED et al. } \\
\text { Cassol OJ Jr et al }\end{array}$ \\
\hline
\end{tabular}

Note: $\sqrt{ }$ Indicates the presence of either in vitro or in vivo studies, or both.

Abbreviations: PBMCs, peripheral blood mononuclear cells; TNF- $\alpha$, tumour necrosis factor-alpha, IFN- $\gamma$, interferon-gamma.

macrophage mobilisation to sites of inflammation, ${ }^{85,88}$ and dendritic cell migration. ${ }^{89} \mathrm{CB} 1$ receptor agonists downregulate mast cell activation and relieve the inflammatory symptoms mediated by hypersensitivity reactions. ${ }^{90}$ On the other hand, CBD can decrease the number of neutrophils and compromise myeloperoxidase activity. ${ }^{59}$

Another mechanism by means of which cannabinoids control immune function is the induction of regulatory cells. CBD can induce myeloid-derived suppressor cells in a mouse model of hepatitis, ${ }^{11}$ and CBD, THC and CB2selective cannabinoids can induce a regulatory phenotype by shifting the balance between inflammatory Th17 and regulatory $\mathrm{T}$ cells, ${ }^{59,67,80,92,93}$ which is mirrored by the induction of anti-inflammatory cytokines and reduction in proinflammatory cytokines. CBD can suppress many transcription factors, including NFAT, AP-1 and NF-kB, and this probably accounts for its widespread suppression of many cytokines. ${ }^{59}$ It also prevents NLRP3/inflammasome pathway activation and suppresses the gene expression of downstream proteins, thus decreasing the production of IL-1 $\beta .{ }^{94}$

The selective activation of CB2 receptors induces IL10 by increasing its production by macrophages, ${ }^{95}$ downregulates $\mathrm{NF}-\mathrm{\kappa B}^{92}$ (it is known that IL-10 production is increased in cannabis users), ${ }^{96}$ and reduces the LPS- induced up-regulation of the genes associated with inflammation in macrophages. ${ }^{85}$

THC inhibits interferon (IFN)-gamma secretion, which is also inhibited by $\mathrm{CBD}^{11,59}$ both directly (by means of a transcriptional mechanism) and indirectly by suppressing the expression of IFN-gamma receptors and increasing the IFN-gamma-induced genes that subsequently attenuate other immune targets. Consistently, CBD decreases IL-2 production in $\mathrm{T}$ cells, ${ }^{97}$ and the engagement of both $\mathrm{CB}$ receptors reduces IL-2 synthesis. ${ }^{98} \mathrm{CBD}$ and THC also attenuate the expression of TNF- $\alpha{ }^{11}$

Finally, various studies have shown that both THC and CBD decrease the production and release of IL- $6,{ }^{99}$ and the action of CBD has been replicated in animal models of inflammation. $^{59}$

These findings are particularly important in the context of autoimmune diseases, but it is always necessary to remember the difficulties of applying translational cannabinoid research to human immune functions. Some in vitro and animal data suggest that the immunomodulatory activity of THC and CB2 agonists can decrease resistance to infectious agents, which is comparable with the immunosuppressive effect of the drugs used to treat autoimmune diseases, ${ }^{9}$ whereas other data suggest that chronic THC exposure may actually help in the case 
of some viral diseases. ${ }^{100}$ Another example is the higher expression of a translocator protein in long-term cannabis users, which is a marker of microglial activation and inflammation. ${ }^{101}$ Furthermore, although CB receptor binding is important in the immunomodulatory action of the cannabis plant, it has to be reminded that some compounds, mainly $\mathrm{CBD}$, have many $\mathrm{CB}$ receptor independent activities.

\section{Medical Cannabis and Autoimmune Diseases}

Cannabinoids immunomodulating traits span on a variety of cell, from lymphocytes and macrophages to chondrocytes. These cells, all take place in the pathogenesis of various autoimmune disease. As each autoimmune disease differ in symptoms, it also differs in the "culpable" immune cells and cytokines inciting the disease. Hence, declaring that cannabis treatment is beneficial for autoimmune diseases does not suffice, and treatment options should be tailored for each disease. For instance, RA is characterized by elevated levels of TNF-a, IL-1 and IL-6 while IL-10 has an attenuating effect on the inflammation. Focusing on specific cannabinoids reveals that $\mathrm{CBD}, \mathrm{THC}$ and $\mathrm{CBG}$ all reduce the levels of TNF-a, a known therapeutic target in the case of RA. Moreover, CBD also reduces IL- 6 levels as mentioned above, pinpointing him as possibly the most suitable treatment for RA. While TNF-a is also a valid target in the treatment of MS, and naturally there is an overlap in cytokine profile of various autoimmune disease, MS is also driven by the presence of IFN- $\gamma$, thus highlighting THC as a likely candidate for therapeutic options. The vast diversity of cannabinoids and their wide range of action on immune cells advocates a tailored approach. Moreover, some autoimmune diseases such as juvenile idiopathic arthritis have been shown to associate with a variation in CB2 receptor, suggesting that cannabis or cannabinoid treatment should possibly be tailored not only per disease but also per person.

The endocannabinoid system, particularly CB2 receptor activation, is a possible target for the treatment of diseases characterised by immune cell activation, such as inflammatory and autoimmune diseases, ${ }^{18,102-104}$ on the basis of the mechanisms described above and shown in Figure 1. The data concerning the efficacy and side effects of the different MC preparations are still limited, and many physicians prefer to avoid suggesting their use, ${ }^{18,105}$ however, there has been abundant pre-clinical research in this area, as can be seen from the following examples.

\section{Rheumatoid Arthritis (RA)}

Cannabinoids interrelation with RA is implied by $\mathrm{CB}$ receptors expression in synovia of RA patients along

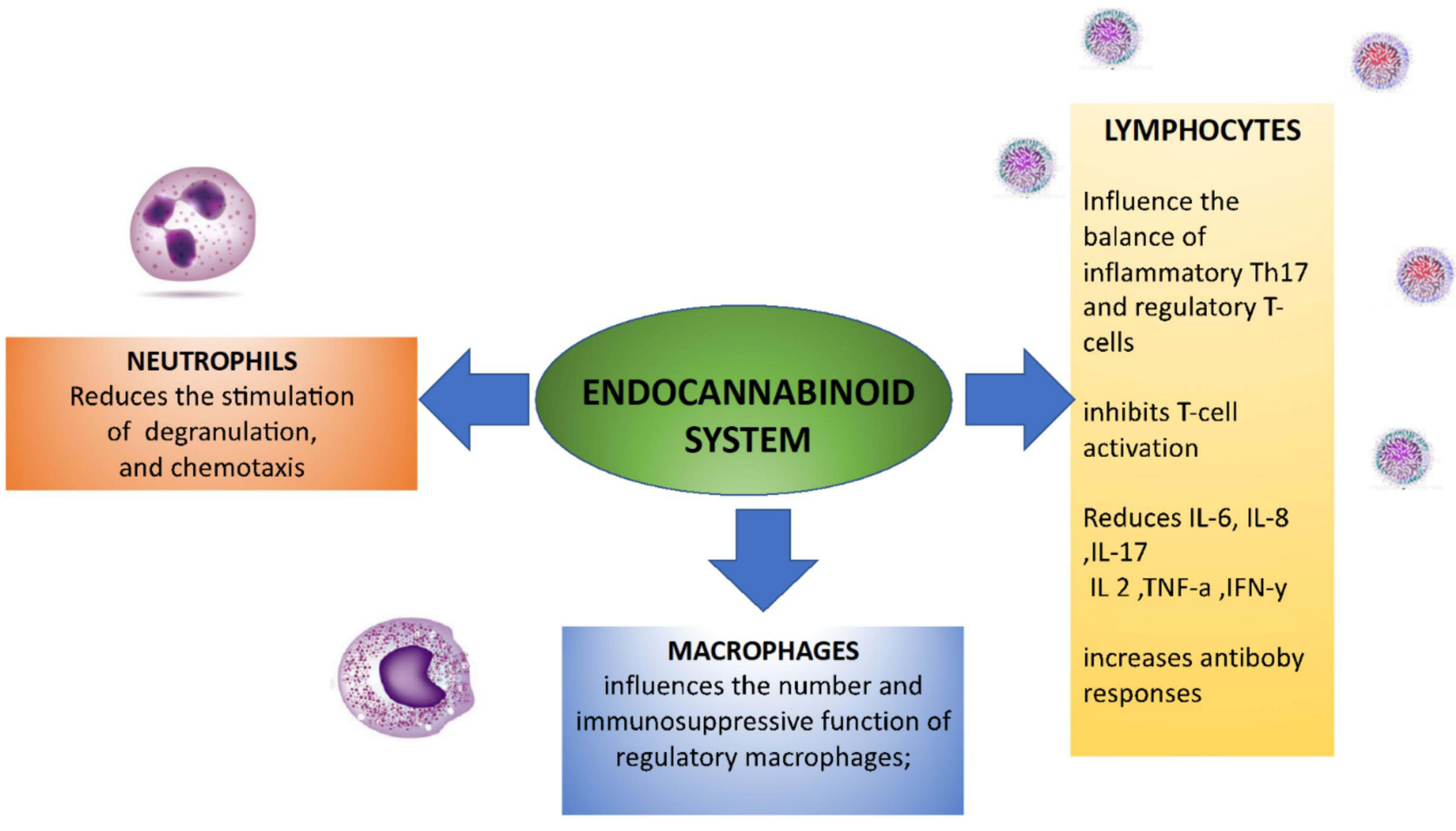

Figure I The endocannabinoid system is a key regulator of the immune system and therefore may be used as a target for the treatment of autoimmune diseases. 
with relatively high levels of endocannabinoids. ${ }^{106}$ The expression of $\mathrm{CB}$ receptors in the inflamed joint advocates the application of cannabinoids as therapeutic agents in RA due to their immunomodulating properties as mentioned in the previous sections.

It has been shown in vitro that non-selective synthetic cannabinoids reduce the production of IL- 6 and IL- 8 by RA fibroblast-like synovial cells, ${ }^{67}$ and that CBD increases intracellular calcium levels and reduces the viability and IL-6/IL-8/ MMP-3 production of RA synovial fibroblasts. ${ }^{107}$ This is particularly interesting as IL-6 is considered a key player not only in RA inflammation but also in the pain, fatigue and mood disorders of RA patients. ${ }^{108,109}$ In mouse models, CBD (and particularly $\mathrm{CB} 2$ receptor activation) decreases synovitis and attenuates the progression of arthritis by reducing inflammatory cell infiltration, bone destruction, the production of anticollagen type II, IgG1 and IFN-gamma, and the release of TNF. $^{70,110}$ The anti-inflammatory effects of endocannabinoids on synovial fibroblasts may also be achieved indirectly using FAAH inhibitors. ${ }^{68}$ Interestingly, in vitro culture in the presence of CBD significantly increased Th17 cell differentiation in CD4+ $\mathrm{T}$ cells from the peripheral blood of patients with RA. ${ }^{111}$

There are currently no randomised clinical trials investigating the use of cannabis in the treatment of RA, partly because of the availability of effective biological antiinflammatory agents in the therapeutic armamentarium. ${ }^{112}$ However, one preliminary randomised, placebo-controlled study has assessed the efficacy, tolerability and safety of five weeks' treatment with a synthetic TCH analogue in 58 RA patients, and found that pain was significantly reduced and disease activity significantly suppressed. ${ }^{113}$

\section{Multiple Sclerosis (MS)}

In mouse models of MS, which are created using mice with experimental autoimmune encephalomyelitis (EAE), the crucial role of the endocannabinoid system in attenuating disease activity is highlighted by the fact that clinical remission is observed in mice with lower FAAH levels ${ }^{114}$ and that CB2 receptor knock-out mice have worse clinical EAE scores than wild-type mice. CB2-negative $\mathrm{T}$ cells are characterised by reduced levels of apoptosis, higher proliferation rates, and increased inflammatory cytokine production ${ }^{79}$ and, in line with this, CB2 receptor engagement in EAE models reduces many markers of inflammation (including iNOS, COX-2, TNF, and IL-1b). ${ }^{115} \mathrm{CB} 1$ receptors may also be involved given their abundance in the central nervous system. ${ }^{116} \mathrm{MC}$ and cannabinoid-based medicines are currently being investigated and used to treat MS-associated spasticity, ${ }^{117-119}$ but whether they can modify the neuroinflammation that causes progressive disability is still an open question: however, even if they cannot induce robust immunosuppression, they could still help by inhibiting the glial responses that facilitate neurodegeneration. ${ }^{120}$

\section{Inflammatory Bowel Disease (IBD)}

The use of MC to treat inflammatory bowel disease is supported by the findings of preclinical studies showing that the endocannabinoid system plays a role in regulating intestinal inflammation. ${ }^{121}$ In many animal models of colitis, the administration of $\mathrm{CB} 1$ or $\mathrm{CB} 2$ receptor agonists ${ }^{122-124}$ and the inhibition of FAAH has prevented or reduced colonic inflammation, ${ }^{125,126}$ and it has been found that $\mathrm{CB} 1$ and $\mathrm{CB} 2$ knockout mice are more susceptible to chemically induced colitis. $^{123,127}$

Furthermore, immunohistochemical studies of humans have shown that the expression of $\mathrm{CB} 2$ receptors is amplified during inflammatory flares, thus suggesting that they are a potential therapeutic target. ${ }^{128,129}$ It is possible that the use of oral formulations may be more successful as it has been discovered that the THC and CBD they contain can efficiently reach the intestinal lymphatic system. ${ }^{11} \mathrm{MC}$ can also have beneficial effects on the permeability of the gastrointestinal tract. $^{130}$

Surveys and cross-sectional studies of IBD patients have shown that many of them smoke usually illegally obtained cannabis in order to alleviate their symptoms. The symptoms that are reported to improve the most are abdominal pain and cramps, appetite, ${ }^{131,132}$ and nausea. ${ }^{133}$ One 2014 study ${ }^{132}$ found that the use of cannabis correlated with a need for surgery, but a more recent study ${ }^{134}$ showed that the prevalence of partial or total colectomy was lower in cannabis users than non-users, and that there was also a trend towards a lower prevalence of bowel obstruction. A recent Australian survey found that clinical severity ratings were not different between cannabis users and non-users, but the former reported more hospitalisations, less engagement with specialist services, and less adherence to prescribed medications; the IBD that were positively affected by cannabis included abdominal pain, stress, sleep, cramping, and anxiety. ${ }^{135}$

The first retrospective study of the clinical use of MC dates back to $2011^{136}$ and, since then, researchers have concentrated more on the different compositions of the MC preparations used to treat IBD. The findings of one 
study suggest that CBD-only MC preparations are not effective for Crohn's disease, ${ }^{137}$ and a study of a very small patient cohort by the same group found that a more THC-rich preparation induced significant, steroid-free clinical benefits. ${ }^{138}$ Furthermore, the use of MC capsules with a high $\mathrm{CBD} / \mathrm{THC}$ ratio has led to improvements in the partial Mayo score, the patients' subjective global impression of disease activity, and physicians global assessments of disease severity, ${ }^{139}$ although there were many dropouts due to THC-related adverse events. Finally, a recent small study found that inhaled THC did not improve disease markers or remission rates in a cohort of 127 ulcerative colitis patients, but did improve disease activity scores. ${ }^{140}$

\section{Conclusions}

The complexity of PCs and their wide range of interactions with multiple potential therapeutic targets support the legalisation of the medicinal use of the world's oldest and best-known illicit drug, especially on the basis of observational studies, ${ }^{141}$ and emerging knowledge of autoimmunity and the high density of $\mathrm{CB} 2$ receptors on immune cells makes the endocannabinoid system a natural target for the treatment of inflammatory and autoimmune diseases. ${ }^{142}$ In vitro and animal studies of multiple sclerosis have provided convincing evidence of the immunomodulatory properties of cannabis, although there is still a lack of clinical evidence from randomised and controlled clinical trials. However, given our limited knowledge of the long-term safety and efficacy of cannabis and its possible drug-drug interactions, it is still too early to make any definite recommendations concerning the cannabinoid treatment of autoimmune diseases, and this should only prompt further research in order to fill these gaps.

\section{Acknowledgment}

We would like to thank Daphna Katz, Itai Katz and Prof. Yehuda Shoenfeld for having revised the manuscript and having added a crucial part about cannabis applications for autoimmune diseases.

\section{Disclosure}

All of the authors declare that they have no conflict of interest in relation to this paper.

\section{References}

1. Bonini SA, Premoli M, Tambaro S, et al. Cannabis sativa: a comprehensive ethnopharmacological review of a medicinal plant with a long history. J Ethnopharmacol. 2018;227:300-315. doi:10.1016/j.jep.2018.09.004

2. Touw M. The religious and medicinal uses of cannabis in China, India and Tibet. $J$ Psychoactive Drugs. 1981;13:23-34. doi:10.1080/02791072.1981.10471447

3. Chopra IC, Chopra RN. The use of the cannabis drugs in India. Bull Narc. 1957;9:4-29.

4. Hall W. The Indian Hemp Drugs Commission 1893-1894. Addiction. 2019;114(9):1679-1682.

5. Hanuš LO, Meyer SM, Muñoz E, Taglialatela-Scafati O, Appendino G. Phytocannabinoids: a unified critical inventory. Nat Prod Rep. 2016;33:1357-1392. doi:10.1039/C6NP00074F

6. Gaoni Y, Mechoulam R. Isolation, structure, and partial synthesis of an active constituent of Hashish. $J$ Am Chem Soc. 1964;86:1646-1647. doi:10.1021/ja01062a046

7. Russell C, Rueda S, Room R, Tyndall M, Fischer B. Routes of administration for cannabis use - basic prevalence and related health outcomes: a scoping review and synthesis. Int $J$ Drug Policy. 2018;52:87-96. doi:10.1016/j.drugpo.2017.11.008

8. Mechoulam R, Fride E, Di Marzo V. Endocannabinoids. Eur J Pharmacol. 1998;359:1-18. doi:10.1016/S0014-2999(98)00649-9

9. Cabral GA, Rogers TJ, Lichtman AH. Turning over a new leaf: cannabinoid and endocannabinoid modulation of immune function. $J$ Neuroimmune Pharmacol. 2015;10:193-203. doi:10.1007/s11481-015-9615-z

10. Pertwee RG. Cannabinoid pharmacology: the first 66 years. $\mathrm{Br}$ J Pharmacol. 2006;147:S163-S171. doi:10.1038/sj.bjp.0706406

11. Zgair A, Lee JB, Wong JCM, et al. Oral administration of cannabis with lipids leads to high levels of cannabinoids in the intestinal lymphatic system and prominent immunomodulation. Sci Rep. 2017;7:1-12. doi:10.1038/s41598-017-15026-z

12. Gould J. 4 Big questions. Nature. 2015;527:4. doi:10.1038/ nj7577-265a

13. Wang T, Collet J-P, Shapiro S, Ware MA. Adverse effects of medical cannabinoids: a systematic review. CMAJ. 2008;178:1669-1678. doi:10.1503/cmaj.071178

14. Fitzcharles MA, Baerwald C, Ablin J, Häuser W. Efficacy, tolerability and safety of cannabinoids in chronic pain associated with rheumatic diseases (fibromyalgia syndrome, back pain, osteoarthritis, rheumatoid arthritis): a systematic review of randomized controlled trials. Schmerz. 2016;30:47-61. doi:10.1007/s00482-015-0084-3

15. Aviram J, Samuelly-Leichtag G. Efficacy of cannabis-based medicines for pain management: a Systematic Review and MetaAnalysis of Randomized Controlled Trials. Pain Physician. 2017;6:E755-E796. doi:10.36076/ppj.20.5.E755

16. Maccallum CA, Russo EB. Practical considerations in medical cannabis administration and dosing. Eur $J$ Intern Med. 2018;49:12-19. doi:10.1016/j.ejim.2018.01.004

17. Ryberg E, Larsson N, Sjögren S, et al. The orphan receptor GPR55 is a novel cannabinoid receptor. $\mathrm{Br} J$ Pharmacol. 2007;152:1092-1101. doi:10.1038/sj.bjp.0707460

18. Almogi-Hazan O, Or R. Cannabis, the endocannabinoid system and immunity - the journey from the bedside to the bench and back. Int J Mol Sci. 2020;21:1-17. doi:10.3390/ijms21124448

19. Capasso R, Borrelli F, Aviello G, et al. Cannabidiol, extracted from cannabis sativa, selectively inhibits inflammatory hypermotility in mice. Br J Pharmacol. 2008;154:1001-1008. doi:10.1038/bjp.2008.177

20. Massi P, Valenti M, Vaccani A, et al. 5-Lipoxygenase and anandamide hydrolase (FAAH) mediate the antitumor activity of cannabidiol, a non-psychoactive cannabinoid. $J$ Neurochem. 2008;104:1091-1100. doi:10.1111/j.1471-4159.2007.05073.x 
21. Oláh A, Szekanecz Z, Bíró T. Targeting cannabinoid signaling in the immune system: "High"-ly exciting questions, possibilities, and challenges. Front Immunol. 2017;8:1. doi:10.3389/fimmu.2017.01487

22. Devane WA, Hanus L, Breuer A, et al. Isolation and structure of a brain constituent that binds to the cannabinoid receptor. Science. 1992;258:1946-1949. doi:10.1126/science.1470919

23. Sugiura T, Kondo S, Sukagawa A, et al. 2-Arachidonoylglycerol: a possible endogenous cannabinoid receptor ligand in brain. Biochem Biophys Res Commun. 1995;215:89-97.

24. Laezza C, Pagano C, Navarra G, et al. The endocannabinoid system: a target for cancer treatment. Int J Mol Sci. 2020;21. doi:10.3390/ijms21030747

25. Perisetti A, Rimu AH, Khan SA, Bansal P, Goyal H. Role of cannabis in inflammatory bowel diseases. Ann Gastroenterol. 2020;33:134-144. doi:10.20524/aog.2020.0452

26. Di Marzo V, De Petrocellis L. Why do cannabinoid receptors have more than one endogenous ligand? Philos Trans $R$ Soc B Biol Sci. 2012;367:3216-3228.

27. Jourdan T, Djaouti L, Demizieux L, Gresti J, Vergès B, Degrace P. CB1 antagonism exerts specific molecular effects on visceral and subcutaneous fat and reverses liver steatosis in diet-induced obese mice. Diabetes. 2010;59:926-934. doi:10.2337/db09-1482

28. Busquets Garcia A, Soria-Gomez E, Bellocchio L, Marsicano G. Cannabinoid receptor type-1: breaking the dogmas. F1000Research. 2016;5:1-9. doi:10.12688/f1000research.8245.1

29. Munro S, Thomas KL, Abu-Shaar M. Molecular characterization of a peripheral receptor for cannabinoids. Nature. 1993;365:61-65. doi:10.1038/365061a0

30. Kinsey SG, Mahadevan A, Zhao B, et al. The CB2 cannabinoid receptor-selective agonist $\mathrm{O}-3223$ reduces pain and inflammation without apparent cannabinoid behavioral effects. Neuropharmacology. 2011;60:244-251. doi:10.1016/j.neuropharm.2010.09.004

31. Núñez E, Benito C, Pazos MR, et al. Cannabinoid CB2 receptors are expressed by perivascular microglial cells in the human brain: an immunohistochemical study. Synapse. 2004;53:208-213.

32. Galiègue S, Mary S, Marchand J, et al. Expression of central and peripheral cannabinoid receptors in human immune tissues and leukocyte subpopulations. Eur J Biochem. 1995;232:54-61. doi:10.1111/j.1432-1033.1995.tb20780.x

33. Parolaro D. Presence and functional regulation of cannabinoid receptors in immune cells. Life Sci. 1999;65:637-644. doi:10.1016/S0024-3205(99)00286-6

34. Kaplan BLF, Springs AEB, Kaminski NE. The profile of immune modulation by cannabidiol (CBD) involves deregulation of nuclear factor of activated T cells (NFAT). Biochem Pharmacol. 2008;76:726-737. doi:10.1016/j.bcp.2008.06.022

35. Ligresti A, De Petrocellis L, Di Marzo V. From phytocannabinoids to cannabinoid receptors and endocannabinoids: pleiotropic physiological and pathological roles through complex pharmacology. Physiol Rev. 2016;96:1593-1659. doi:10.1152/ physrev.00002.2016

36. Sharma CV, Long JH, Shah S, et al. First evidence of the conversion of paracetamol to AM404 in human cerebrospinal fluid. J Pain Res. 2017;10:2703-2709. doi:10.2147/JPR.S143500

37. Pertwee RG. The diverse CB 1 and CB 2 receptor pharmacology of three plant cannabinoids: $\Delta$ 9-tetrahydrocannabinol, cannabidiol and $\Delta$ 9-tetrahydrocannabivarin. $\mathrm{Br} J$ Pharmacol. 2008;153:199-215. doi:10.1038/sj.bjp.0707442

38. Pisanti S, Malfitano AM, Ciaglia E, et al. Cannabidiol: state of the art and new challenges for therapeutic applications. Pharmacol Ther. 2017;175:133-150. doi:10.1016/j.pharmthera.2017.02.041

39. Laprairie RB, Bagher AM, Kelly MEM, Denovan-Wright EM. Cannabidiol is a negative allosteric modulator of the cannabinoid CB1 receptor. Br J Pharmacol. 2015;172:4790-4805. doi:10.1111/ bph. 13250
40. Morgan CJA, Schafer G, Freeman TP, Curran HV. Impact of cannabidiol on the acute memory and psychotomimetic effects of smoked cannabis: naturalistic study. $\mathrm{Br} J$ Psychiatry. 2010;197:285-290. doi:10.1192/bjp.bp.110.077503

41. Woelfl T, Rohleder C, Mueller JK, et al. Effects of cannabidiol and delta-9-tetrahydrocannabinol on emotion, cognition, and attention: a Double-Blind, Placebo-Controlled, Randomized Experimental Trial in Healthy Volunteers. Front Psychiatry. 2020;11. doi:10.3389/fpsyt.2020.576877

42. Russo EB, Marcu J. Cannabis pharmacology: the usual suspects and a few promising leads. Adv Pharmacol. 2017;80:67-134.

43. Gonçalves ECD, Baldasso GM, Bicca MA, Paes RS, Capasso R, Dutra RC. Terpenoids, cannabimimetic ligands, beyond the cannabis plant. Molecules. 2020;25:1567. doi:10.3390/molecules25071567

44. Mammana S, Cavalli E, Gugliandolo A, et al. Could the combination of two non-psychotropic cannabinoids counteract neuroinflammation? Effectiveness of cannabidiol associated with cannabigerol. Med. 2019;55. doi:10.3390/medicina55110747

45. Udoh M, Santiago M, Devenish S, McGregor IS, Connor M. Cannabichromene is a cannabinoid CB2 receptor agonist. $\mathrm{Br}$ J Pharmacol. 2019;176:4537-4547. doi:10.1111/bph.14815

46. Bento AF, Marcon R, Dutra RC, et al. $\beta$-caryophyllene inhibits dextran sulfate sodium-induced colitis in mice through CB2 receptor activation and PPAR $\gamma$ pathway. Am J Pathol. 2011;178:1153-1166. doi:10.1016/j.ajpath.2010.11.052

47. de Almeida AAC, Silva RO, Nicolau LAD, et al. Physiopharmacological investigations about the anti-inflammatory and antinociceptive efficacy of (+)-limonene epoxide. Inflammation. 2017;40:511-522. doi:10.1007/s10753-016-0496-y

48. Ramalho TR, Filgueiras LR, De Oliveira MTP, et al. GammaTerpinene modulation of LPS-stimulated macrophages is dependent on the PGE2/IL-10 Axis. Planta Med. 2016;82:1341-1345. doi:10.1055/s-0042-107799

49. Pertwee RG. Pharmacology of cannabinoid CB1 and CB2 receptors. Pharmacol Ther. 1997;74:129-180. doi:10.1016/ S0163-7258(97)82001-3

50. Vaughan CW, Christie MJ. Retrograde signalling by endocannabinoids. Handb Exp Pharmacol. 2005;(168):367-83. doi:10.1007/3540-26573-2_12

51. Pisanu A, Acquas E, Fenu S, Di Chiara G. Modulation of $\Delta 9$-THCinduced increase of cortical and hippocampal acetylcholine release by $\mu$ opioid and D1 dopamine receptors. Neuropharmacology. 2006;50:661-670. doi:10.1016/j.neuropharm.2005.11.023

52. Pistis M, Ferraro L, Pira L, et al. Delta(9)-tetrahydrocannabinol decreases extracellular GABA and increases extracellular glutamate and dopamine levels in the rat prefrontal cortex: an in vivo microdialysis study. Brain Res. 2002;948:155-158. doi:10.1016/ S0006-8993(02)03055-X

53. Vrechi TA, Crunfli F, Costa AP, Torrão AS. Cannabinoid receptor Type 1 agonist ACEA protects neurons from death and attenuates endoplasmic reticulum stress-related apoptotic pathway signaling. Neurotox Res. 2018;33:846-855. doi:10.1007/s12640-017-9839-1

54. Xu C, Hermes DJ, Nwanguma B, et al. Endocannabinoids exert $\mathrm{CB} 1$ receptor-mediated neuroprotective effects in models of neuronal damage induced by HIV-1 Tat protein. Mol Cell Neurosci. 2017;83:92-102. doi:10.1016/j.mcn.2017.07.003

55. Saliba SW, Marcotegui AR, Fortwängler E, et al. Correction: AM404, paracetamol metabolite, prevents prostaglandin synthesis in activated microglia by inhibiting COX activity. J Neuroinflammation. 2018;15:34. doi:10.1186/s12974-018-1072-1

56. Lowin T, Apitz M, Anders S, Straub RH. Anti-inflammatory effects of $\mathrm{N}$-acylethanolamines in rheumatoid arthritis synovial cells are mediated by TRPV1 and TRPA1 in a COX-2 dependent manner. Arthritis Res Ther. 2015;17. doi:10.1186/s13075-0150845-5 
57. Watzl B, Scuderi P, Watson RR. Marijuana components stimulate human peripheral blood mononuclear cell secretion of interferon-gamma and suppress interleukin-1 alpha in vitro. Int J Immunopharmacol. 1991;13:1091-1097. doi:10.1016/01920561(91)90160-9

58. Watzl B, Scuderi P, Watson RR. Influence of marijuana components (THC and CBD) on human mononuclear cell cytokine secretion in vitro. Adv Exp Med Biol. 1991:63-70.

59. Nichols JM, Kaplan BLF. Immune responses regulated by cannabidiol. Cannabis Cannabinoid Res. 2020;5:12-31. doi:10.1089/can.2018.0073

60. Wu HY, Chang AC, Wang $\mathrm{CC}$, et al. Cannabidiol induced a contrasting pro-apoptotic effect between freshly isolated and precultured human monocytes. Toxicol Appl Pharmacol. 2010;246:141-147. doi:10.1016/j.taap.2010.05.003

61. Jenny M, Santer E, Pirich E, Schennach H, Fuchs D. $\Delta 9$-Tetrahydrocannabinol and cannabidiol modulate mitogeninduced tryptophan degradation and neopterin formation in peripheral blood mononuclear cells in vitro. $J$ Neuroimmunol. 2009;207:75-82. doi:10.1016/j.jneuroim.2008.12.004

62. Kozela E, Lev N, Kaushansky N, et al. Cannabidiol inhibits pathogenic $\mathrm{T}$ cells, decreases spinal microglial activation and ameliorates multiple sclerosis-like disease in C57BL/6 mice. $\mathrm{Br}$ $J$ Pharmacol. 2011;163:1507-1519. doi:10.1111/j.14765381.2011.01379.x

63. Jan TR, Kaminski NE. Role of mitogen-activated protein kinases in the differential regulation of interleukin-2 by cannabinol. J Leukoc Biol. 2001;69:841-849.

64. Chen W, Kaplan BLF, Pike ST, et al. Magnitude of stimulation dictates the cannabinoid-mediated differential $\mathrm{T}$ cell response to HIV gp120. J Leukoc Biol. 2012;92:1093-1102. doi:10.1189/ jlb.0212082

65. Devinsky O, Patel AD, Thiele EA, et al. Randomized, dose-ranging safety trial of cannabidiol in Dravet syndrome. Neurology. 2018;90:e1204-e1211. doi:10.1212/WNL.000000000 0005254

66. Elliott DM, Singh N, Nagarkatti M, Nagarkatti PS. Cannabidiol attenuates experimental autoimmune encephalomyelitis model of multiple sclerosis through induction of myeloid-derived suppressor cells. Front Immunol. 2018;9. doi:10.3389/fimmu.2018.01782

67. Selvi E, Lorenzini S, Garcia-Gonzalez E, et al. Inhibitory effect of synthetic cannabinoids on cytokine production in rheumatoid fibroblast-like synoviocytes. Clin Exp Rheumatol. 2008;26:574-581.

68. Kinsey SG, Naidu PS, Cravatt BF, Dudley DT, Lichtman AH. Fatty acid amide hydrolase blockade attenuates the development of collagen-induced arthritis and related thermal hyperalgesia in mice. Pharmacol Biochem Behav. 2011;99:718-725. doi:10.1016/ j.pbb.2011.06.022

69. Gentili M, Ronchetti S, Ricci E, et al. Selective CB2 inverse agonist JTE907 drives T cell differentiation towards a Treg cell phenotype and ameliorates inflammation in a mouse model of inflammatory bowel disease. Pharmacol Res. 2019;141:21-31. doi:10.1016/j.phrs.2018.12.005

70. Malfait AM, Gallily R, Sumariwalla PF, et al. The nonpsychoactive cannabis constituent cannabidiol is an oral anti-arthritic therapeutic in murine collagen-induced arthritis. Proc Natl Acad Sci U S A. 2000;97:9561-9566. doi:10.1073/pnas.160105897

71. Shapiro CM, Orlina AR, Unger P, Billings AA. Antibody response to cannabis. JAMA. 1974;230:81-82. doi:10.1001/ jama.1974.03240010049030

72. McHugh D, Tanner C, Mechoulam R, Pertwee RG, Ross RA. Inhibition of human neutrophil chemotaxis by endogenous cannabinoids and phytocannabinoids: evidence for a site distinct from CB1 and CB 2. Mol Pharmacol. 2008;73:441-450. doi:10.1124/ mol.107.041863
73. Walter L, Franklin A, Witting A, et al. Nonpsychotropic cannabinoid receptors regulate microglial cell migration. $J$ Neurosci. 2003;23:1398-1405. doi:10.1523/JNEUROSCI.23-04-01398.2003

74. Giudice ED, Rinaldi L, Passarotto M, et al. Cannabidiol, unlike synthetic cannabinoids, triggers activation of RBL-2H3 mast cells. J Leukoc Biol. 2007;81:1512-1522. doi:10.1189/jlb.1206738

75. Cassol OJ Jr, Comim CM, Silva BR, et al. Treatment with cannabidiol reverses oxidative stress parameters, cognitive impairment and mortality in rats submitted to sepsis by cecal ligation and puncture. Brain Res. 2010;1348:128-138. doi:10.1016/j.brainres.2010.06.023

76. El-Gohary M, Eid MA. Effect of cannabinoid ingestion (in the form of bhang) on the immune system of high school and university students. Hum Exp Toxicol. 2004;23:149-156. doi:10.1191/0960327104ht426oa

77. Jan TR, Su ST, Wu HY, Liao MH. Suppressive effects of cannabidiol on antigen-specific antibody production and functional activity of splenocytes in ovalbumin-sensitized BALB/c mice. Int Immunopharmacol. 2007;7:773-780. doi:10.1016/j. intimp.2007.01.015

78. Dotsey E, Ushach I, Pone E, et al. Transient cannabinoid receptor 2 blockade during immunization heightens intensity and breadth of antigen-specific antibody responses in young and aged mice. Sci Rep. 2017;7. doi:10.1038/srep42584

79. Maresz K, Pryce G, Ponomarev ED, et al. Direct suppression of CNS autoimmune inflammation via the cannabinoid receptor CB1 on neurons and $\mathrm{CB} 2$ on autoreactive $\mathrm{T}$ cells. Nat Med. 2007;13:492-497. doi:10.1038/nm1561

80. Rieder SA, Chauhan A, Singh U, Nagarkatti M, Nagarkatti P. Cannabinoid-induced apoptosis in immune cells as a pathway to immunosuppression. Immunobiology. 2010;215:598-605. doi:10.1016/j.imbio.2009.04.001

81. Schwarz H, Blanco FJ, Lotz M. Anadamide, an endogenous cannabinoid receptor agonist inhibits lymphocyte proliferation and induces apoptosis. J Neuroimmunol. 1994;55:107-115. doi:10.1016/0165-5728(94)90152-X

82. Chiurchiù V, Lanuti M, Catanzaro G, Fezza F, Rapino C, Maccarrone M. Detailed characterization of the endocannabinoid system in human macrophages and foam cells, and anti-inflammatory role of type-2 cannabinoid receptor. Atherosclerosis. 2014;233:55-63. doi:10.1016/j.atherosclerosis.2013.12.042

83. Staiano RI, Loffredo S, Borriello F, et al. Human lung-resident macrophages express $\mathrm{CB} 1$ and $\mathrm{CB} 2$ receptors whose activation inhibits the release of angiogenic and lymphangiogenic factors. J Leukoc Biol. 2016;99:531-540. doi:10.1189/jlb.3HI1214-584R

84. Lee WS, Erdelyi K, Matyas C, et al. Cannabidiol limits T cellmediated chronic autoimmune myocarditis: implications to autoimmune disorders and organ transplantation. Mol Med. 2016;22:136-146. doi:10.2119/molmed.2016.00007

85. Persidsky Y, Fan S, Dykstra H, Reichenbach NL, Rom S, Ramirez SH. Activation of cannabinoid type two receptors (CB2) diminish inflammatory responses in macrophages and brain endothelium. $J$ Neuroimmune Pharmacol. 2015;10:302-308. doi:10.1007/s11481-015-9591-3

86. Kishimoto S, Kobayashi Y, Oka S, Gokoh M, Waku K, Sugiura T. 2-Arachidonoylglycerol, an endogenous cannabinoid receptor ligand, induces accelerated production of chemokines in HL-60 cells. J Biochem. 2004;135:517-524. doi:10.1093/jb/mvh063

87. Roth MD, Castaneda JT, Kiertscher SM. Exposure to $\Delta$ 9-tetrahydrocannabinol impairs the differentiation of human monocyte-derived dendritic cells and their capacity for $\mathrm{T}$ cell activation. $J$ Neuroimmune Pharmacol. 2015;10:333-343. doi:10.1007/s11481-015-9587-z

88. Kapellos TS, Taylor L, Feuerborn A, et al. Cannabinoid receptor 2 deficiency exacerbates inflammation and neutrophil recruitment. FASEB J. 2019;33:6154-6167. doi:10.1096/fj.201802524R 
89. Adhikary S, Kocieda VP, Yen JH, Tuma RF, Ganea D. Signaling through cannabinoid receptor 2 suppresses murine dendritic cell migration by inhibiting matrix metalloproteinase 9 expression. Blood. 2012;120:3741-3749. doi:10.1182/blood2012-06-435362

90. Nam G, Jeong SK, Park BM, et al. Selective cannabinoid receptor-1 agonists regulate mast cell activation in an oxazolone-induced atopic dermatitis model. Ann Dermatol. 2016;28:22-29. doi:10.5021/ad.2016.28.1.22

91. Hegde VL, Singh UP, Nagarkatti PS, Nagarkatti M. Critical role of mast cells and peroxisome proliferator-activated receptor $\gamma$ in the induction of myeloid-derived suppressor cells by marijuana cannabidiol in vivo. $J$ Immunol. 2015;194:5211-5222. doi:10.4049/jimmunol.1401844

92. Robinson RH, Meissler JJ, Fan X, Yu D, Adler MW, Eisenstein TK. A CB2-selective cannabinoid suppresses T-cell activities and increases Tregs and IL-10. J Neuroimmune Pharmacol. 2015;10 (2):318-332. doi:10.1007/s11481-015-9611-3

93. Stebulis JA, Johnson DR, Rossetti RG, Burstein SH, Zurier RB. Ajulemic acid, a synthetic cannabinoid acid, induces an antiinflammatory profile of eicosanoids in human synovial cells. Life Sci. 2008;83:666-670. doi:10.1016/j.lfs.2008.09.004

94. Peyravian N, Deo S, Daunert S, Jimenez JJ. Cannabidiol as a novel therapeutic for immune modulation. ImmunoTargets Ther. 2020;9:131-140. doi:10.2147/ITT.S263690

95. Correa F, Mestre L, Docagne F, Guaza C. Activation of cannabinoid CB 2 receptor negatively regulates IL-12p40 production in murine macrophages: role of IL-10 and ERK1/2 kinase signaling. $\mathrm{Br}$ J Pharmacol. 2005;145:441-448. doi:10.1038/sj.bjp.0706215

96. Abo-Elnazar S, Moaaz M, Ghoneim H, Molokhia T, El-Korany W. Th17/Treg imbalance in opioids and cannabinoids addiction: relationship to $\mathrm{NF}-\kappa \mathrm{B}$ activation in $\mathrm{CD} 4+\mathrm{T}$ cells. Egypt J Immunol. 2014;21:33-47.

97. Castillo PE, Younts TJ, Chávez AE, Hashimotodani Y. Endocannabinoid signaling and synaptic function. Neuron. 2012;76:70-81. doi:10.1016/j.neuron.2012.09.020

98. Börner C, Smida M, Höllt V, Schraven B, Kraus J. Cannabinoid receptor type 1- and 2-mediated increase in cyclic AMP inhibits $\mathrm{T}$ cell receptor-triggered signaling. $J$ Biol Chem. 2009;284:35450-35460. doi:10.1074/jbc.M109.006338

99. Katz-Talmor D, Katz I, Porat-Katz BS, Shoenfeld Y. Cannabinoids for the treatment of rheumatic diseases - where do we stand? Nat Rev Rheumatol. 2018;14:488-498. doi:10.1038/ s41584-018-0025-5

100. Molina PE, Amedee AM, Winsauer P, Nelson S, Bagby G, Simon L. Behavioral, metabolic, and immune consequences of chronic alcohol or cannabinoids on HIV/AIDs: studies in the non-human primate SIV model. J Neuroimmune Pharmacol. 2015;10:217-232. doi:10.1007/s11481-015-9599-8

101. Da silva T, Hafizi S, Watts JJ, et al. In vivo imaging of translocator protein in long-term cannabis users. JAMA Psychiatry. 2019;76:1305-1313. doi:10.1001/jamapsychiatry.2019.2516

102. Di Marzo V. New approaches and challenges to targeting the endocannabinoid system. Nat Rev Drug Discov. 2018;17:623-639.

103. Śledziński P, Nowak-Terpiłowska A, Zeyland J. Cannabinoids in medicine: cancer, immunity, and microbial diseases. Int J Mol Sci. 2021;22:1-22.

104. Sarzi-Puttini P, Batticciotto A, Atzeni F, et al. Medical cannabis and cannabinoids in rheumatology: where are we now? Expert Rev Clin Immunol. 2019;15:1019-1032. doi:10.1080/ 1744666X.2019.1665997

105. Fitzcharles M-A, Ste-Marie PA, Clauw DJ, et al. Rheumatologists lack confidence in their knowledge of cannabinoids pertaining to the management of rheumatic complaints. BMC Musculoskelet Disord. 2014;15:258. doi:10.1186/1471-2474-15-258
106. Richardson D, Pearson RG, Kurian N, et al. Characterisation of the cannabinoid receptor system in synovial tissue and fluid in patients with osteoarthritis and rheumatoid arthritis. Arthritis Res Ther. 2008;10:R43. doi:10.1186/ar2401

107. Lowin T, Tingting R, Zurmahr J, Classen T, Schneider M, Pongratz G. Cannabidiol (CBD): a killer for inflammatory rheumatoid arthritis synovial fibroblasts. Cell Death Dis. 2020;11:1-11. doi:10.1038/s41419-020-02892-1

108. Atzeni F, Nucera V, Masala IF, Sarzi-Puttini P, Bonitta G. Il-6 Involvement in pain, fatigue and mood disorders in rheumatoid arthritis and the effects of Il-6 inhibitor sarilumab. Pharmacol Res. 2019;149:104402. doi:10.1016/j.phrs.2019.104402

109. Fonseca JE, Santos MJ, Canhão H, Choy E. Interleukin-6 as a key player in systemic inflammation and joint destruction. Autoimmun Rev. 2009;8:538-542. doi:10.1016/j.autrev.2009.01.012

110. Gui H, Liu X, Liu LR, Su DF, Dai SM. Activation of cannabinoid receptor 2 attenuates synovitis and joint distruction in collagen-induced arthritis. Immunobiology. 2015;220:817-822. doi:10.1016/j.imbio.2014.12.012

111. Kotschenreuther K, Waqué I, Yan S, et al. Cannabinoids drive Th17 cell differentiation in patients with rheumatic autoimmune diseases. Cell Mol Immunol. 2021;18:764-766. doi:10.1038/ s41423-020-0437-4

112. Sarzi-Puttini P, Ablin J, Trabelsi A, Fitzcharles MA, Marotto D, Häuser W. Cannabinoids in the treatment of rheumatic diseases: pros and cons. Autoimmun Rev. 2019;18:102409. doi:10.1016/j. autrev.2019.102409

113. Blake DR, Robson P, Ho M, Jubb RW, McCabe CS. Preliminary assessment of the efficacy, tolerability and safety of a cannabis-based medicine (Sativex) in the treatment of pain caused by rheumatoid arthritis. Rheumatology. 2006;45:50-52. doi:10.1093/rheumatology/kei183

114. Webb M, Luo L, Ma JY, Tham CS. Genetic deletion of Fatty Acid Amide Hydrolase results in improved long-term outcome in chronic autoimmune encephalitis. Neurosci Lett. 2008;439:106-110. doi:10.1016/j.neulet.2008.04.090

115. Wen J, Ribeiro R, Tanaka M, Zhang Y. Activation of CB2 receptor is required for the therapeutic effect of ABHD6 inhibition in experimental autoimmune encephalomyelitis. Neuropharmacology. 2015;99:196-209. doi:10.1016/j.neuropharm.2015.07.010

116. De Lago E, Moreno-Martet M, Cabranes A, Ramos JA, FernándezRuiz J. Cannabinoids ameliorate disease progression in a model of multiple sclerosis in mice, acting preferentially through CB1 receptor-mediated anti-inflammatory effects. Neuropharmacology. 2012;62:2299-2308. doi:10.1016/j.neuropharm.2012.01.030

117. Paolicelli D, Direnzo V, Manni A, et al. Long-term data of efficacy, safety, and tolerability in a real-life setting of $\mathrm{THC} /$ CBD oromucosal spray-treated multiple sclerosis patients. J Clin Pharmacol. 2016;56:845-851. doi:10.1002/jcph.670

118. Celius EG, Vila C. The influence of THC:CBD oromucosal spray on driving ability in patients with multiple sclerosis-related spasticity. Brain Behav. 2018;8(5):e00962. doi:10.1002/brb3.962

119. Zettl UK, Rommer P, Hipp P, Patejdl R. Evidence for the efficacy and effectiveness of THC-CBD oromucosal spray in symptom management of patients with spasticity due to multiple sclerosis. Ther Adv Neurol Disord. 2016;9:9-30. doi:10.1177/1756285615612659

120. Baker D, Jackson SJ, Pryce G. Cannabinoid control of neuroinflammation related to multiple sclerosis. $\mathrm{Br} J$ Pharmacol. 2007;152:649-654. doi:10.1038/sj.bjp.0707458

121. Pesce M, D'Alessandro A, Borrelli O, et al. Endocannabinoidrelated compounds in gastrointestinal diseases. $J$ Cell $\mathrm{Mol} \mathrm{Med.}$ 2018;22:706-715. doi:10.1111/jcmm.13359

122. Storr MA, Keenan CM, Zhang H, Patel KD, Makriyannis A, Sharkey KA. Activation of the cannabinoid 2 receptor (CB2) protects against experimental colitis. Inflamm Bowel Dis. 2009;15:1678-1685. doi:10.1002/ibd.20960 
123. Massa F, Marsicano G, Hermann H, et al. The endogenous cannabinoid system protects against colonic inflammation. J Clin Invest. 2004;113:1202-1209. doi:10.1172/JCI200419465

124. D’Argenio G, Valenti M, Scaglione G, Cosenza V, Sorrentini I, Di Marzo V. Up-regulation of anandamide levels as an endogenous mechanism and a pharmacological strategy to limit colon inflammation. FASEB J. 2006;20:568-570. doi:10.1096/fj.054943fje

125. Sałaga M, Mokrowiecka A, Zakrzewski PK, et al. Experimental colitis in mice is attenuated by changes in the levels of endocannabinoid metabolites induced by selective inhibition of fatty acid amide hydrolase (FAAH). J Crohns Colitis. 2014;8:998-1009. doi:10.1016/j.crohns.2014.01.025

126. Alhouayek M, Lambert DM, Delzenne NM, Cani PD, Muccioli GG. Increasing endogenous 2-arachidonoylglycerol levels counteracts colitis and related systemic inflammation. FASEB J. 2011;25:2711-2721. doi:10.1096/fj.10-176602

127. Engel MA, Kellermann CA, Burnat G, Hahn EG, Rau T, Konturek PC. Mice lacking cannabinoid CB1-, CB2-receptors or both receptors show increased susceptibility to trinitrobenzene sulfonic acid [TNBS]-induced colitis. J Physiol Pharmacol. 2010;61:89-97.

128. Marquéz L, Suárez J, Iglesias M, Bermudez-Silva FJ, Rodríguez de Fonseca F, Andreu M. Ulcerative colitis induces changes on the expression of the endocannabinoid system in the human colonic tissue. PLoS One. 2009;4:e6893. doi:10.1371/journal. pone. 0006893

129. Duncan M, Mouihate A, Mackie K, et al. Cannabinoid CB2 receptors in the enteric nervous system modulate gastrointestinal contractility in lipopolysaccharide-treated rats. Am J Physiol Gastrointest Liver Physiol. 2008;295:G78-G87. doi:10.1152/ ajpgi.90285.2008

130. Couch DG, Cook H, Ortori C, Barrett D, Lund JN, O'Sullivan SE. Palmitoylethanolamide and cannabidiol prevent inflammation-induced hyperpermeability of the human gut in vitro and in vivo-a Randomized, Placebo-controlled, Double-blind Controlled Trial. Inflamm Bowel Dis. 2019;25:1006-1018. doi:10.1093/ibd/izz017

131. Lal S, Prasad N, Ryan M, et al. Cannabis use amongst patients with inflammatory bowel disease. Eur J Gastroenterol Hepatol. 2011;23:891-896. doi:10.1097/MEG.0b013e328349bb4c

132. Storr M, Devlin S, Kaplan GG, Panaccione R, Andrews CN. Cannabis use provides symptom relief in patients with inflammatory bowel disease but is associated with worse disease prognosis in patients with Crohn's disease. Inflamm Bowel Dis. 2014;20:472-480. doi:10.1097/01.MIB.0000440982.79036.d6
133. Allegretti JR, Courtwright A, Lucci M, Korzenik JR, Levine J. Marijuana use patterns among patients with inflammatory bowel disease. Inflamm Bowel Dis. 2013;19:2809-2814. doi:10.1097/01. MIB.0000435851.94391.37

134. Mbachi C, Attar B, Oyenubi O, et al. Association between cannabis use and complications related to ulcerative colitis in hospitalized patients: a propensity matched retrospective cohort study. Med (United States). 2019;98. doi:10.1097/ MD.0000000000016551

135. Benson MJ, Abelev SV, Connor SJ, et al. Medicinal cannabis for inflammatory bowel disease: a survey of perspectives, experiences, and current use in Australian patients. Crohns Colitis. 2020;2:1-15

136. Naftali T, Lev LB, Yablekovitz D, Half E, Konikoff FM. Treatment of Crohn's disease with cannabis: an observational study. Isr Med Assoc J. 2011;13:455-458.

137. Naftali T, Mechulam R, Marii A, et al. Low-dose cannabidiol is safe but not effective in the treatment for Crohn's disease, a Randomized Controlled Trial. Dig Dis Sci. 2017;62:1615-1620. doi:10.1007/s10620-017-4540-z

138. Naftali T, Bar-Lev Schleider L, Dotan I, Lansky EP, Sklerovsky Benjaminov F, Konikoff FM. Cannabis induces a clinical response in patients with crohn's disease: a prospective placebocontrolled study. Clin Gastroenterol Hepatol. 2013;11(10):12761280.e1. doi:10.1016/j.cgh.2013.04.034

139. Irving PM, Iqbal $\mathrm{T}$, Nwokolo $\mathrm{C}$, et al. A Randomized, Double-blind, Placebo-controlled, Parallel-group, Pilot Study of Cannabidiol-rich Botanical Extract in the Symptomatic Treatment of Ulcerative Colitis. Inflamm Bowel Dis. 2018;24:714-724. doi:10.1093/ibd/izy002

140. Naftali T, Bar-Lev Schleider L, Sklerovsky Benjaminov F, Lish I, Konikoff FM, Ringel Y. Medical cannabis for inflammatory bowel disease: real-life experience of mode of consumption and assessment of side-effects. Eur $J$ Gastroenterol Hepatol. 2019;31:1376-1381. doi:10.1097/MEG.0000000000001565

141. Giorgi V, Bongiovanni S, Atzeni F, Marotto D, Salaffi F, SarziPuttini P. Adding medical cannabis to standard analgesic treatment for fibromyalgia: a prospective observational study. Clin Exp Rheumatol. 2020;38:53-59.

142. Katz D, Katz I, Porat-Katz BS, Shoenfeld Y. Medical cannabis: another piece in the mosaic of autoimmunity? Clin Pharmacol Ther. 2017;101:230-238. doi:10.1002/cpt.568

\section{Publish your work in this journal}

ImmunoTargets and Therapy is an international, peer-reviewed open access journal focusing on the immunological basis of diseases, potential targets for immune based therapy and treatment protocols employed to improve patient management. Basic immunology and physiology of the immune system in health, and disease will be also covered. In addition, the journal will focus on the impact of management programs and new therapeutic agents and protocols on patient perspectives such as quality of life, adherence and satisfaction. The manuscript management system is completely online and includes a very quick and fair peer-review system, which is all easy to use. Visit http://www.dovepress.com/testimonials.php to read real quotes from published authors. 